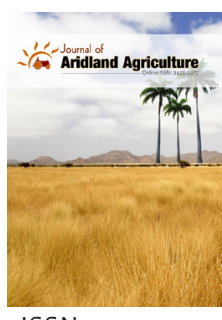

ISSN: $2455-9377$

Received: January 31, 2021 Revised: August 07, 2021

Accepted: August 09, 2021

Published: September 10, 2021

*Corresponding author:

Seval Eliş

E-mail: elis_sseval@hotmail.

com

\section{Dual-purpose ability of barley and wheat at drought and heat stress conditions}

\author{
Seval Eliș*, Mehmet Yıldırım \\ Department of Field Crops, Faculty of Agriculture, University of Dicle, 21280 Diyarbakir, Turkey
}

\begin{abstract}
Dual-purpose barley and wheat production is a valuable resource to fill feed gaps and grain production, but availability at drought and heat stress conditions is still not clearly studied. Two experiments were conducted at semi-controlled green house to determine biomass production at vegetative stages, chlorophyll content and grain yield. Experiment 1 consists of four clipping treatments on wheat, i.e. one, two, three times clipping and un-clipping control. Experiment 2 combined two clipping treatments (one clipping and un-clipping) and two levels of water (low: $40 \%$ of field capacity; normal: $85 \%$ of field capacity) on barley. Wheat grain yield was severely affected by increasing clipping number under heat stress. Total biomass at one clipping was the same level with control treatment. Although physiological maturity was delayed 8 days from control to 3 times clipping application, biomass and yield remained below the control application due to shrinkage in plant height and other organs size. Clipping and water levels at barley significantly impacted biomass and plant height, but all traits were not related by interactions clipping $\mathrm{x}$ water level. The clipping application in heat stress reduced total biomass by 21.3 and $30.4 \%$ in well-watered and dry conditions, respectively. Contrary to what is expected, it seems clear to obtain satisfactory forage and grain yield by optimizing the management technique, growing in dual-purpose production in wheat and barley in warm environments.
\end{abstract}

KEYWORDS: wheat, barley, drought, heat stress, dual-purpose

\section{INTRODUCTION}

Continuous World population growth reveals both vegetable and animal food production insufficiency and nutritional problems. Due to the limited arable lands in the world, food production and nutrition problems can be solved only by improving the sustainability of animal and vegetable production by using the existing agricultural areas in the most accurate way. It is an important sustainability method to graze winter products in the agricultural system in a dual-purpose production system in a way that does not affect cereal grain yield and provide the necessary forage (Harrison et al., 201 la).

In the world, wheat has 219.5 million ha ${ }^{-1}$ cultivation area, 3.43 tons ha $\mathrm{a}^{-1}$ yield, and 744.7 million tons total production (FAO, 2018). Wheat, which is the most correct plant for dual-purpose production, has a great share in world agricultural production is one of the important basic nutrients in human nutrition and is important for animal nutrition as a green feed source.

The forage needed in animal production is mostly met from natural meadow-pasture areas and paddock plants. Factors such as the misuse of meadow pasture lands, intensive and timeless grazing and the negative effects of global climate change make it difficult to supply feed needed by livestock. In order to overcome the lack of quality green feed, which is one of the main problems of livestock enterprises, especially in the winter season animal nutrition, alternative options should be developed to provide feed. This requirement can be met by winter crops (barley, wheat, canola, oats, etc.) by both clip or grazing the animals to provide green feed and obtaining grain yield by using it for dual purposes. Early winter grazing during the product development positively affects the grain yield by reducing above-ground dry matter growth, delaying of anthesis and shortening of height (Winter \& Thompson, 1990; Dean, 2007). Due to their slow growth properties, winter wheat and canola varieties offer long-term grazing and produce a significant amount of the dry matter before reaching the critical stage where grazing is terminated, and therefore they are the most studied and used dual-purpose plants (Kirkegaard et al., 2016).

Australia is one of the countries where winter cereals are grown dual-purpose as both green feed and grain products. Many Farmers in the grain production belt in Western Australia experience feed gaps in early winter. The dominant reason for this is that pasture is growing slowly at the

Copyright: $\odot$ The authors. This article is open access and licensed under the terms of the Creative Commons Attribution License (http://creativecommons.org/licenses/by/4.0/) which permits unrestricted, use, distribution and reproduction in any medium, or format for any purpose, even commercially provided the work is properly cited. Attribution - You must give appropriate credit, provide a link to the license, and indicate if changes were made. 
beginning, the grass density is low and it is also negatively affected by grazing. Grain yield and quality did not decrease when the barley plants were grazed to $5 \mathrm{~cm}$ for 17 days with 10 sheep in a 3.6 ha area after reaching the 3-4 leaf stage in Western Australia. Anthesis time is delayed 8 days (Fosberry \& Joyce, 2015). Winter type cereal varieties when sown in April and grazed in winter, grazing did not have a significant effect on grain yield. Grazing significantly increased the yield of 2 varieties and had no significant effect on the other 5 varieties. Grazing did not affect grain quality enough to change the grain classification achieved by a majority of varieties trialed (Handley \& Warren, 2015). Grazing once in early and late sowing ended an increase in yield in wheat and barley, while the yield in oat decreased. The second grazing caused a decrease in yield in all plant species. It has been determined that grazing does not cause a change in grain quality (Barret, 2015). In cereals, early sowing have low yields compared to optimum sowing time (Edwards et al., 2011). Grazing increased the proportion of water lost through soil evaporation but decreased transpiration, reducing shoot dry matter production per unit evapotranspiration by up to $22 \%$. However, grazing did not affect grain yield per unit evapotranspiration. For rainfed wheat crops grown in temperate environments, greater biomass production occurred with shorter rather than longer grazing durations, irrespective of grazing intensities. (Harrison et al., 2011b). In Southeast Australia, the effect of different clipping times and heights on dry grass production in irrigated and dry conditions was investigated, and the highest dry matter production was obtained in late and high form in wet conditions. In the related irrigation regimes, there was no significant difference between the grain yields of different clipping applications (Zeleke, 2019)

Overall, responses of grazing to late sowing and heat stress environment are still not clearly elucidated. In particular, studies of dual-purpose are lacking in irrigated areas for spring type cereals under heat stress. Further, the impact of dual-purpose growing mainly focused on winter wheat and barley, but using spring type plants for his aim, received little attention (Arzadun et al., 2003; Kelman \& Dove, 2009; Kirkegaard et al., 2016).

In this study, two greenhouse experiments were established in heat stress conditions to assess dual-purpose ability of spring wheat and barley by testing under different clipping and water effects.

\section{MATERIAL AND METHODS}

This study was carried out in two different experiments in Dicle University Faculty of Agriculture under semi-controlled greenhouse conditions in 2019. In the first experiment, in which the effects of different clipping numbers on green and dry grass and grain were examined, the "Empire" spring bread wheat variety was used. The second trial, which was carried out in well-watered and dry conditions, where the clipping treatment was done once in order to obtain green and dry grass was planted on 04.05.2019 using the six-rowed spring "Keçiburcu" barley genotype.
The physical and chemical properties of the soil samples used in the study are as shown in Table 1. Plastic pots with an upperlower width of $16-13 \mathrm{~cm}$ and a height of $23 \mathrm{~cm}$ were filled with 4.6 kilograms of soil. The soil in all the pots was saturated with water and overnight so that it would reach the field capacity before sowing. 8 seeds were planted in the pots and after the emergence, 4 plants were left in each pot. Nitrogen and $\mathrm{P}$ were initially applied $0.03 \mathrm{~g} \mathrm{NH}_{4} \mathrm{NO}_{3}$ and as $0.03 \mathrm{~g} \mathrm{P}_{2} \mathrm{O}_{5}$ per pot, respectively. $0.07 \mathrm{~g} \mathrm{~N}$ was applied 30 days after sowing.

The first experiment was established according to the trial randomized plot design with six replicate and the plants were watered as needed. In this experiment, 4 different clipping treatments were applied; these controlled [no clip $(\mathrm{C} 0)$ ], one clipping GS25 according to the Zadoks growth scale (Zadoks et al., 1974) on 11 March (C1), two clipping on 11 March and 25 March (C2), three clipping on 11 March, 25 March and 08 April (C3). Clip point elevated to $6 \mathrm{~cm}$ above ground level and it is not removed any growing points in any of treatments. After each clipping, the fresh shoot weight (forage) of each pot (with a semi analytical balance with $0,001 \mathrm{~g}$ precision) was weighed and put on separate paper bags and dried in an oven at $70^{\circ} \mathrm{C}$ for 48 hours to determine dry weight. Chlorophyll content was determined in the SPAD unit at heading time using Minolta SPAD 502 chlorophyll meter. Plant height was measured before harvest. Plants were harvested in the physiological maturity period on May 24, May 27, June 1 and June 9 for C0, C1, C2 and $\mathrm{C} 3$ treatment, respectively. In the harvest, all the above ground parts of the plant were clipped with scissors. The stems and leaves of the plants in each pot and their ears were dried separately in the oven and biomass and spike weight were determined. After threshing grain yield, grain number and grain weight were determined.

The second experiment was set up with two factors according to the factorial experiment design, factor A; two clipping treatment (C0: control or no clip, $\mathrm{Cl}$ : one clipping) and factor $\mathrm{B}$; two different water applications (WW: well water, WS: water stress). In the clipping treatment $(\mathrm{Cl})$, the clipping was made on May 29. Wet and dry shoot weight (forage) were determined in the above ground parts. All pots in the control and clipping

Table 1: The physical and chemical properties of the soil samples used in Expt 1 and Expt 2

\begin{tabular}{lcc}
\hline Soil properties & Unit & Value \\
\hline Clay & $\%$ & 7900 \\
pH & & 7,61 \\
ECe & $\mathrm{dS} \mathrm{m}^{-1}$ & 085 \\
Kireç $\left(\mathrm{CaCO}_{3}\right)$ & $\%$ & 643 \\
Organic matter & $\%$ & 2,88 \\
Phosphorus $\left(\mathrm{P}_{2} \mathrm{O}_{5}\right)$ & $\mathrm{kg} / \mathrm{da}^{-1}$ & 178,79 \\
Potassium $\left(\mathrm{K}_{2} \mathrm{O}\right)$ & $\mathrm{kg}_{\mathrm{da}} \mathrm{da}^{-1}$ & 498,56 \\
Calcium $(\mathrm{Ca})$ & $\mathrm{mg} \mathrm{kg}^{-1}$ & 8588,85 \\
Magnesium $(\mathrm{Mg})$ & $\mathrm{mg} \mathrm{kg}^{-1}$ & 300,14 \\
Iron $(\mathrm{Fe})$ & $\mathrm{mg} \mathrm{kg}^{-1}$ & 1,99 \\
Copper $(\mathrm{Cu})$ & $\mathrm{mg} \mathrm{kg}^{-1}$ & 2,12 \\
Zinc $(\mathrm{Zn})$ & $\mathrm{mg} \mathrm{kg}^{-1}$ & 3,51 \\
Mangan $(\mathrm{Mn})$ & $\mathrm{mg} \mathrm{kg}^{-1}$ & 10,46 \\
Molybdenum $(\mathrm{Mo})$ & $\mathrm{mg} \mathrm{kg}^{-1}$ & 0,34 \\
Extractable Sodium $(\mathrm{Na})$ & $\mathrm{mg} \mathrm{kg}^{-1}$ & 394,94 \\
\hline
\end{tabular}

J Aridland Agric • $2021 \quad$ V Vol 7 
treatment were irrigated to $85 \%$ of the field capacity from sowing to the GS47 period (late booting). Irrigation differentiation started from this period. In well water conditions (WW), the field capacity is irrigated to $85 \%$, and in water stress (WS) conditions, the amount of water in the pot is watered every day to $40 \%$ of the field capacity. WW and WS pots were weighed every morning and the evaporation amount was determined and the reduced water was added to the pots. Plants completed their development in the greenhouse at the ambient temperature of $24-32 \pm 2^{\circ} \mathrm{C}, 50-55 \%$ relative humidity and daylight. The traits of SPAD, plant height, biomass, heading time and water use efficiency (WEU) were measured. WUE was calculated as the ratio of biomass to crop evapotranspiration per pot $\left(\mathrm{mg} \mathrm{g}^{-1}\right)$ at WS treatment.

The effects of clipping treatment and water stress on investigated traits were tested by repeated measures by ANOVA. When $F$-values were significant, multiple comparisons of means were performed using the least significant difference method (LSD) at 0.05 probability. All statistical analysis was done with JMP 13 statistical software. The correlation coefficient between properties was determined according to Pearson in the same program.

\section{RESULTS AND DISCUSSION}

The data of the variance analysis results of the properties examined in the study of different clipping treatment in wheat are given in Table 2. Clipping treatments significantly affected all traits (Zadoks scale, plant height, physiological maturity, leaf + stem weight, spike weight, biomass, biomass + dry grass weight, grain weight, grain number, grain yield) except the SPAD unit. The mean values of the different clipping treatments of the examined properties and the groupings showing the differences between them are given in Table 3 . When we look at the averages that show the general growth stage (GS) according to the different clipping treatments on the $66^{\text {th }}$ day after sowing, it is seen that the control plants $(\mathrm{C} 0)$ complete the flowering period and go to the grain filling stage. While it is seen that the plants that are applied one time clipping (Cl) have passed to anthesis, the plants that are applied two times clipping $(\mathrm{C} 2)$ begin to spike emergence, and in the three times clipping $(\mathrm{C} 3)$, it is observed that the plants are late in the development period and are in the middle of the booting stage (Fig.1). This shows that as the clipping number increases, plants will mature later. Grazing delayed head emergence and flowering when compared to the ungrazed treatment and delayed barley development by about a week (Fosberry \& Joyce, 2015). There was a difference in physiological maturity among all clipping practices. While physiological maturity was close to the control in one clipping, the two clipping remained 8 days more green compared to the control and 18 days longer than the three clipping. Since drought is eliminated in the experiment, especially in multi clipping applications such as $\mathrm{C} 2$ and $\mathrm{C} 3$, the fact that the plants remain green for a long time in extremely high temperatures shows that heat resistance mechanisms occur in plants. (Holman et al., 2009; Dean, 2007; Royo et al., 2006).

The SPAD unit representing the amount of chlorophyll, which is an important part of the photosynthesis apparatus, is not affected by clipping treatment. Therefore, it can be said that the photosynthesis process works at a similar rate in all applications. In this case, changes in yield and biomass may be influenced by morphological changes depending on the clipping rather than metabolic events.

Plant height and stem+leaf weight parameters were significantly affected by the number of clipping and decreased linearly due to the increase in the number of clipping (Table 3 ). Decreases in stem + leaf weight, biomas and spike weight were more severe than plant height. Plant height decreased by 16,5$30,0 \%$ in C2-C3, while stem + leaf decreased by 42-66\%, respectively. $\mathrm{Cl}$ application did not cause a decrease in spike weight compared to control, and a decrease in C2 spike weight was less than stem+leaf weight. However, in C3, the spike weight decreased more severely than the stem+leaf weight. This may have caused the plants to enter the warmer period with the developmental delay caused by the $3^{\text {rd }}$ clipping (C3) and not enough time for spike formation and dry matter to accumulate in the spike.

Table 2: Influence of clipping number on investigated traits of spring wheat

\begin{tabular}{|c|c|c|c|c|c|c|c|c|c|c|c|c|}
\hline SOURCE & DF & $\begin{array}{l}\text { Growth } \\
\text { Stage }\end{array}$ & $\begin{array}{l}\text { Physiological } \\
\text { maturity }\end{array}$ & SPAD & Plant height (cm) & Leaf + Shoot weight & $\begin{array}{c}\text { Spike } \\
\text { weight }\end{array}$ & Biomass & $\begin{array}{l}\text { Biomass } \\
+ \text { forage }\end{array}$ & $\begin{array}{c}\text { Grain } \\
\text { weight }\end{array}$ & Grain number & Grain yield \\
\hline Clipping & 3 & $678,56 *$ & $382,37^{*}$ & 10,50 & $799,20 *$ & $37,28^{*}$ & $86,41^{*}$ & $236,40 *$ & $173,08^{*}$ & $45,15^{*}$ & $34544,10^{*}$ & $51,54^{*}$ \\
\hline Error & 20 & $1,25^{*}$ & $0,67 *$ & 4,72 & $8,85^{*}$ & $0,29 *$ & $1,81 *$ & $3,33 *$ & $3,54 *$ & $9,27 *$ & $625,70 *$ & $0,70 *$ \\
\hline CV & & 1,99 & 0,82 & 5,53 & 3,83 & 10,01 & 16,73 & 13,54 & 13,04 & 7,98 & 16,62 & 14,49 \\
\hline
\end{tabular}

* $P<005$

Table 3: Wheat grain yield and other investigated traits as affected by clipping number

\begin{tabular}{|c|c|c|c|c|c|c|c|c|c|c|c|}
\hline $\begin{array}{l}\text { Clipping } \\
\text { number }\end{array}$ & $\begin{array}{c}\text { Growth } \\
\text { Stage }\end{array}$ & $\begin{array}{l}\text { Physiological } \\
\text { maturity (day) }\end{array}$ & SPAD (unit) & Plant height $(\mathrm{cm})$ & $\begin{array}{l}\text { Leaf }+ \text { Shoot } \\
\text { weight }\left(\mathrm{g} \mathrm{pot}^{-1}\right)\end{array}$ & $\begin{array}{c}\text { Spike weigh } \\
\left(\text { g pot }^{-1}\right)\end{array}$ & $\begin{array}{l}\text { htBiomass } \\
\qquad\left(\mathrm{g} \mathrm{pot}^{-1}\right) \mathrm{fc}\end{array}$ & $\begin{array}{l}\text { Biomass }+ \\
\text { forage }\left(\mathrm{g} \mathrm{pot}^{-1}\right)\end{array}$ & $\begin{array}{c}\text { Grain } \\
1 \text { ) weight }(\mathrm{g})\end{array}$ & $\begin{array}{c}\text { Grain numb } \\
\left(\mathrm{g} \mathrm{pot}^{-1}\right)\end{array}$ & $\begin{array}{l}\text { rGrain yielo } \\
\left(\mathrm{g} \mathrm{pot}^{-1}\right)\end{array}$ \\
\hline $\mathrm{CO}$ & $69,01 a$ & $93^{d}$ & 38,11 & $89,16^{a}$ & $7,95^{\mathrm{a}}$ & $11,40^{\mathrm{a}}$ & $19,35^{\mathrm{a}}$ & $19,35^{\mathrm{a}}$ & $38,20^{a b}$ & $225,16^{a}$ & $8,45^{a}$ \\
\hline $\mathrm{Cl}$ & $60,50 b$ & $95,5^{c}$ & 38,53 & $84,16^{b}$ & $6,62^{b}$ & $10,19^{a}$ & $16,82^{b}$ & $17,38^{a}$ & $38,08^{a b}$ & $189,33^{b}$ & $7,32^{b}$ \\
\hline $\mathrm{C} 2$ & $50,00 c$ & $101^{b}$ & 39,45 & $74,50^{c}$ & $4,97^{c}$ & $7,80^{b}$ & $12,77^{c}$ & $13,90^{b}$ & $41,47^{a}$ & $137,00^{\circ}$ & $5,66^{c}$ \\
\hline C3 & $45,33 d$ & $111^{\mathrm{a}}$ & 41,10 & $63,00^{d}$ & $2,16^{d}$ & $2,82^{c}$ & $4,99^{d}$ & $7,12^{c}$ & $34,75^{b}$ & $50,46^{d}$ & $1,75^{d}$ \\
\hline
\end{tabular}

Means followed by the same letter are not significantly different at $P<005$ according to LSD 


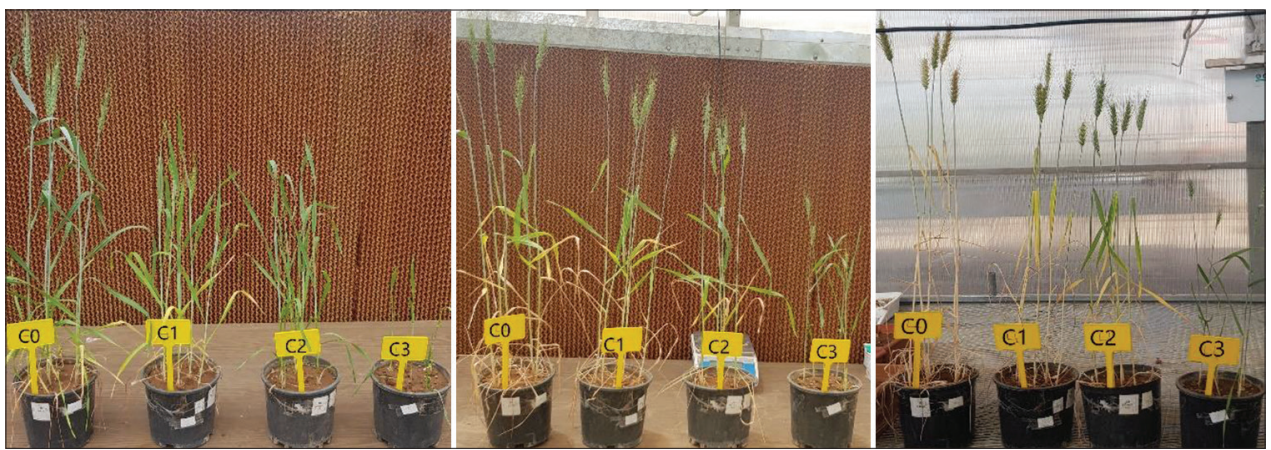

Figure 1: Growing stages differences at $\mathrm{C} 0, \mathrm{C} 1, \mathrm{C} 2$ and $\mathrm{C} 3$ cutting treatment of wheat on $69^{\text {th }}(\mathrm{a}), 82^{\text {th }}(\mathrm{b})$ and $95^{\text {th }}(\mathrm{c})$ days.

In all clipping treatments, there was no relationship between plant height and all other traits, and only in C3, plant height showed a negative correlation $\left(R^{2}=-0,813\right)$ with grain weight. There was a positive correlation between spike weight and stem + leaf in all treatment except for $\mathrm{C} 3\left(\mathrm{R}^{2}=0,93^{* *}, 0,89^{* * *}\right.$, and 0,95 **, for $\mathrm{C} 0, \mathrm{Cl}$ and $\mathrm{C} 2$, respectively).

Although there was a significant decrease in biomass weight as the number of clipping increased, there was no significant difference between $\mathrm{C} 0$ and $\mathrm{Cl}$ applications for the total biomass parameter obtained by collecting dry grass with biomass. According to Winter and Musick (1991) the reduction in biomass at anthesis was correlated with reduced grain yield. Similarly with them report biomass and grain yield negatively correlated at C1, C2, C3 treatment. Research reported by Harwell et al., (1976) suggested that pasturing wheat beyond the jointing stage would severely reduce wheat grain yield, but grazing succulent growth prior to this date would have little or no effect on subsequent wheat grain yield. From the $\mathrm{C} 1, \mathrm{C} 2$ and $\mathrm{C} 3$ treatment, 0,56, 1,06 and $2,14 \mathrm{~g} \mathrm{pot}^{-1}$ dry forage and 3,77, 7,89 and 13,73 $\mathrm{g} \mathrm{pot}^{-1}$ green forage were obtained, respectively (Fig. 2 and 3). Although high dry and green forage was obtained in C3 application, this was not sufficient to increase the total biomass due to an excessive decrease in biomass. When leaf+shoot weights and dry forage weights are evaluated together, forage production in $\mathrm{Cl}$ treatment is not statistically different from control $(\mathrm{C} 0)$. Due to the use of spring wheat cultivar in the experiment and growing in late sowing conditions, the total green grass obtained from the treatment of $\mathrm{C} 3$ represents a significant value in meeting the green grass need by livestock farms (Fig 2). On the other hand, it is stated that from early sowing winter wheat can be obtained both a large amount of dry grass and the green grass required in the winter months and in addition to producing grain yield (Davidson et al., 1990). According to the results of the wheat studies conducted for grazing purposes, Horrison et al., (2011) reported that the optimum benefit can be achieved with the grazing of $160 \mathrm{~g}$ $\mathrm{m}^{-2}$ and this corresponds to $13 \%$ of total biomass. In our study, the amount of weed obtained from 3 clipping was $11 \%$ of the total biomass in the control, which indicates that only green grass can be grown. Although thousand grain weights increased in $\mathrm{Cl}$ and $\mathrm{C} 2$ treatment compared to control, the number of grains showed a severe decrease as the number of clipping increased. Significant decreases were observed in grain yield

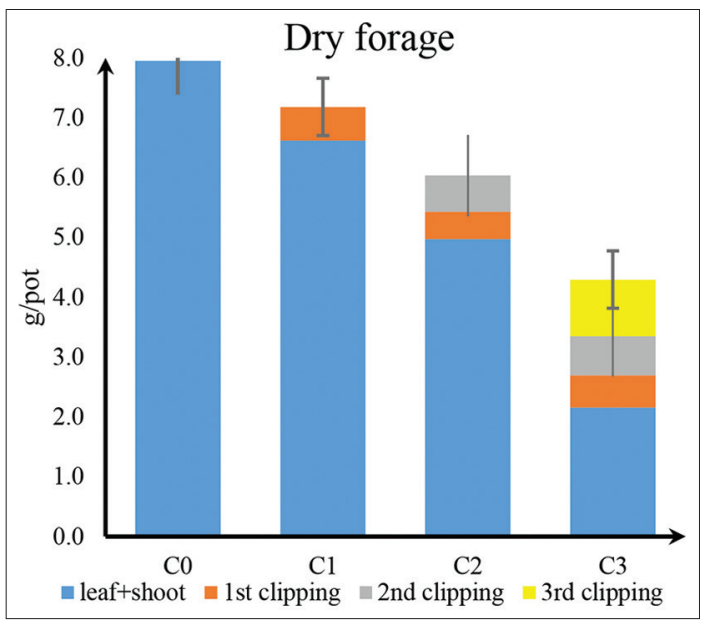

Figure 2: Leaf+shoot and dry forage weight of wheat obtained different clipping treatment

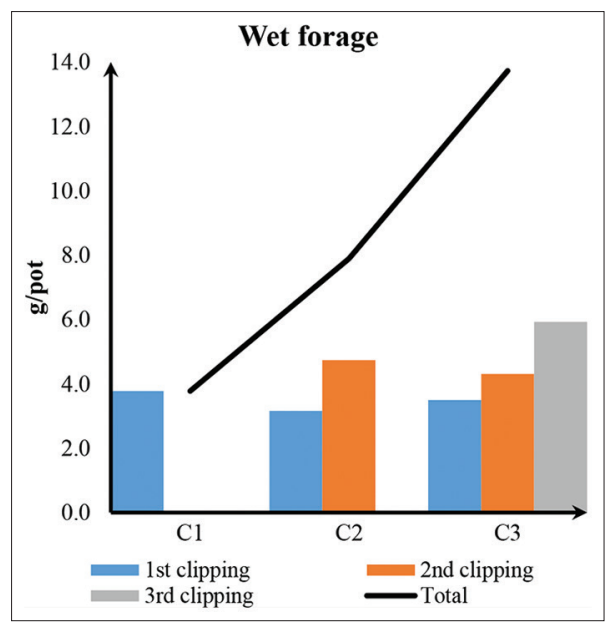

Figure 3: Green forage values of wheat at different clipping treatments Black line is total green forage for each clipping treatment

as clipping frequency increased. Although the $\mathrm{Cl}$ treatment shows a statistically significant decrease in yield compared to control, considering the economic benefit provided by grazing, the sustainability of agriculture is achieved by obtaining a grain and green grass in the spring wheat by making a clipping in late sowing conditions. Although grazing has been reported to have no effect on wheat grain yield (Dove et al., 2002; Winter 
et al., 1990), moderate to high yield declines after grazing has been reported in most previous studies (Winter \& Musick, 1991; Kelman \& Dove, 2007; Harrison et al., 2011a). Wagle et al., (2018) reported that there was a $78 \%$ reduction in grain yield by grazing in winter wheat.

ANOVA results of the properties examined in two different clipping and two different water treatments of barley are given in Table 4. According to Table 4, it is seen that irrigation levels significantly affect all the features, while clipping creates a significant difference in all the traits (plant height, biomass, biomass + dry grass, heading time) except the SPAD unit.

Table 4: Influence of clipping and water treatment on investigated traits of barley

\begin{tabular}{lcccccc}
\hline SOURCE & DF & SPAD & Plant height & Biomass & $\begin{array}{c}\text { Biomass + Heading time } \\
\text { forage }\end{array}$ \\
\hline Clipping & 1 & 5,40 & $357,14^{*}$ & $15,53^{*}$ & $5,87^{*}$ & $12,89^{*}$ \\
Water & 1 & $96,20^{*}$ & $63,00^{*}$ & $15,59^{*}$ & $16,06^{*}$ & $26,03^{*}$ \\
C x W & 1 & 0,48 & 17,28 & 0,02 & 0,010 & 0,03 \\
Error & 24 & 9,27 & 13,41 & 0,21 & 0,23 & 1,17 \\
CV & & 7,89 & 8,69 & 15,66 & 14,95 & 2,34 \\
\hline
\end{tabular}

$* P<005$

Table 5: SPAD, plant height, biomass, biomass + forage and heading time mean values of barley as affected by clipping and water treatment

\begin{tabular}{lccccc}
\hline Treatments & SPAD (unit) & $\begin{array}{c}\text { Plant } \\
\text { height }(\mathrm{cm})\end{array}$ & $\begin{array}{c}\text { Biomass } \\
\left(\mathrm{g} \mathrm{pot}^{-1}\right)\end{array}$ forage $\left(\mathrm{g} \mathrm{pot}^{-1}\right)$ time (day) \\
\hline Clipping & & & & & \\
Control (C0) & & & & & \\
WW & 39,85 & 46,42 & 4,44 & 4,44 & 46,57 \\
WS & 36,41 & 45,00 & 2,89 & 2,89 & 44,57 \\
Mean & 38,13 & $45,71^{\mathrm{a}}$ & $3,67^{\mathrm{a}}$ & $3,67^{\mathrm{a}}$ & $45,57^{\mathrm{b}}$ \\
Clipping (C1) & & & & & \\
WW & 41,00 & 40,85 & 2,89 & 3,49 & 47,85 \\
WS & 37,02 & 36,28 & 1,46 & 2,01 & 46,00 \\
Mean & 39,01 & $38,57^{\mathrm{b}}$ & $2,18 \mathrm{~b}$ & $2,75^{\mathrm{b}}$ & $46,92^{\mathrm{a}}$ \\
Water & & & & & \\
WW & $40,42^{\mathrm{a}}$ & $43,64^{\mathrm{a}}$ & $3,67^{\mathrm{a}}$ & $3,96^{\mathrm{a}}$ & $47,21^{\mathrm{a}}$ \\
WS & $36,72^{\mathrm{b}}$ & $40,64^{\mathrm{b}}$ & $2,17^{\mathrm{b}}$ & $2,45^{\mathrm{b}}$ & $45,28^{\mathrm{b}}$ \\
\hline
\end{tabular}

Within clipping and water treatment means followed by the same letter are not significantly different at $\mathrm{P}<005$ according to LSD WW:well watered, WS:water stressed

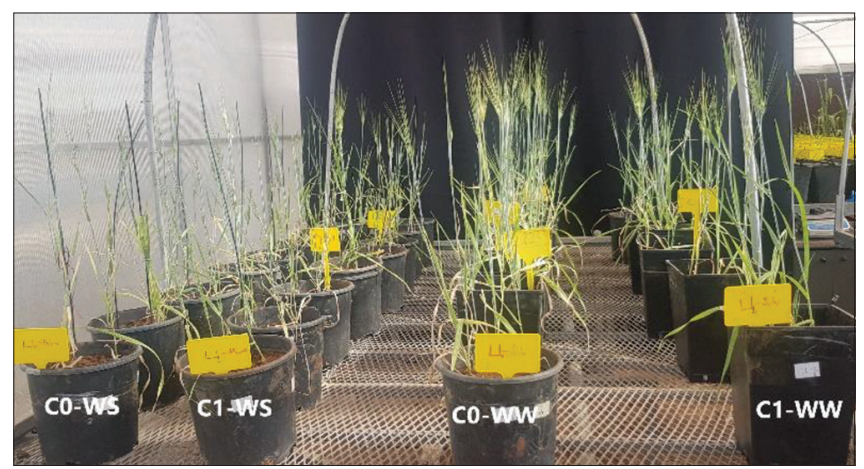

Figure 4: Clipping and irrigation effect on barley growth. C0: control without clipping, C1:one times clipping before shooting stage, WS:water stress and WW: fully irrigation.
Clipping x irrigation interaction effect was found insignificant for all features (Fig.4). This shows that the treatment of the clipping reacts similarly to the irrigation. Irrigation did not affect heading time since the differentiation of irrigation (drought) was initiated from the late booting stage (GS47). Clipping treatment delayed spike formation as in Experiment 1. The delay of heading time between $\mathrm{Cl}$ and $\mathrm{C} 0$ (1.3 days) at Experiment 2 is very low compared to the 9-day difference in the first trial due to the late sowing and exposure to warmer conditions.

In the experiment, the average values of the traits according to clipping and irrigation treatment and the differences between them are given in Table 5. The SPAD unit, which is the determinant of chlorophyll content was not affected by clipping but was affected by water treatment. Abiotic stress factors adversely affect the process of photosynthesis in the plant (Allakhverdiev et al., 2008), and drought and temperature stress greatly reduces the physiological parameters

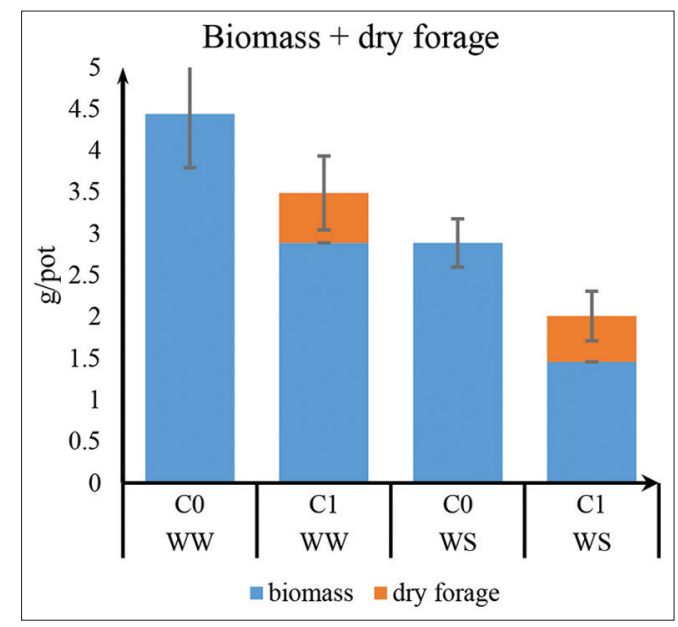

Figure 5: Biomass and dry forage weights of barley showing total dry matter production of clipping effects under different water level (WW and WS)

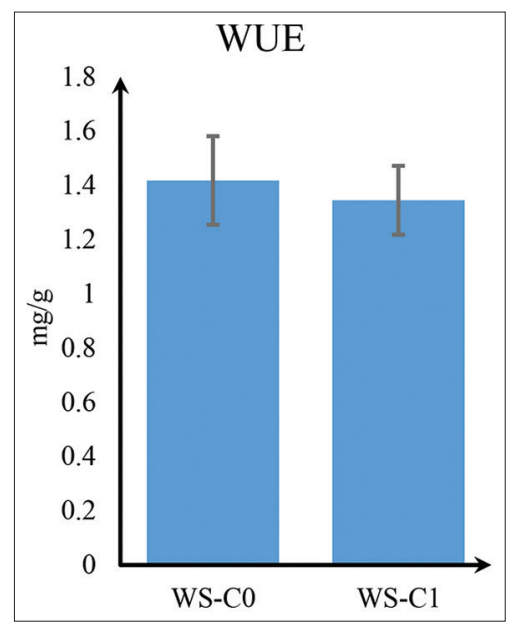

Figure 6: WUE of barley for clipping treatment at water stress conditions 
such as chlorophyll content, photosystem II (PSII) efficiency, stomatal conductance and net assimilation rate (Mishra et al., 2014). The significant decrease in SPAD unit of C0 and Cl in water stress shows that both the process of photosynthesis is negatively affected and the decrease in dry matter is one of the main reasons.

Plant height was significantly affected by irrigation and clipping treatment (Table 5). Plant height in $\mathrm{Cl}$ application decreased by $12 \%$ in WW and $19.4 \%$ in WS conditions compared to C0 treatment, and Water application relatively reduced plant height caused by clipping effect. As in Experiment 1, the clipping treatment reduced biomass twice as much as plant height. The clipping reduced the Biomass + dry forage by $21.3 \%$ in WW conditions and $30.4 \%$ in WS conditions. According to Fig. 5, while there was no significant difference in biomass + forage production between the clipping $(\mathrm{Cl})$ and the control $(\mathrm{C} 0)$ in WW, total dry matter of $\mathrm{Cl}$ in WS negatively affected. In the study carried out by Zeleke (2019), there was a 7\% decrease in irrigated conditions and $15 \%$ in dry conditions for dry matter depending on the clipping. As in our study, irrigation significantly reduced the adverse effect caused by clipping. While the plant shortening and biomass reduction occurring in the clipping are expected to provide an advantage in water consumption in drought conditions, there is no difference in WUE between $\mathrm{Cl}$ and $\mathrm{C} 0$ (Fig 6). This study showed that it is possible to grow wheat and barley as dual purpose production in the warm environment and late sowing conditions. Especially in Northern parts of Africa, some Arab countries and hot climate regions where wheat is grown by irrigation, similar dual purpose studies will be useful for the elimination of the forage gap and the continuity of animal husbandry.

\section{REFERENCES}

Allakhverdiev, S., Kreslavski, V., Klimov, V., Los, D., Carpentier, R., \& Mohanty P. (2008). Heat stress: An overview of molecular responses in photosynthesis. Photosynthesis Research, 98, 541-550. https://doi. org/10.1007/s11120-008-9331-0

Arzadun, M. J., Arroquy, J. I., Laborde, H. E., \& Brevedan, R. E. (2003). Grazing pressure on beef and grain production of dual-purpose wheat in Argentina. Agronomy Journal, 95(5), 1157-1162. https:// doi.org/10.2134/agronj2003.1157

Barret, P. (2015). Managing frost risk in cereals using crop graizing, varietal choiceand time of sowing In "An overview and analysis of trial site results for grazing crops and pastures in the rotation in Western Australia". GRDC Trial Booklet. p:16-19.

Davidson, J. L., Jones, D. B., \& Chrıstıan, K. R. (1990). Winter feed production and grain yield in mixtures of spring and winter wheats. Australian Journal of Agricultural Research, 41, 1-18. https://doi. org/10.1071/AR9900001

Dean, G. (2007). Optimal plant density and the effect of grazing on grain yield of early sown wheat- Epping Forest. Tasmania Southern Farming Systems [2018-01-12] Retrieved from www.ccmaknowledgebase.vic. gov.au/resources/16.pdf

Dove, H., Holst, P.J., Stanley, D.F., Flint, P.W. (2002). Grazing value of dual purpose wheats for young sheep. Animal Production in Australia. 24, 53-56.
Edwards, J. T., Carver, B. F., Horn, G. W., \& Payton, M. E. (2011). Impact of dual-purpose management on wheat grain yield. Crop Science, 51 , 1-5. https://doi.org/10.2135/cropsci2011.01.0043

FAO. (2018). FAOSTAT, Agriculture Database http://appsfaoorg

Fosberry, G., \& Joyce, B. (2015). The Impact of Grazing Cereal Crops in the Eastern Wheat belt. http://wwwgrainandgraze3comau

Handley, M., \& Warren, G. (2015). Esperance Cereal Varieties Trial In "An overview and analysis of trial site results for grazing crops and pastures in the rotation in Western Australia". GRDC Trial Booklet. p:11-15. http://wwwgrainandgraze3comau

Harrison, M. T., Evans, J. R., Dove, H., \& Moore, A. D. (2011a). Dualpurpose cereals: Can the relative influences of management and environment on crop recovery and grain yield be dissected? Crop and Pasture Science, 62, 930-946. https://doi.org/10.1071/CP11066

Harrison, M. T., Evans, J. R., Dove, H., \& Moore, A. D. (2011b). Recovery dynamics of rainfed winter wheat after livestock grazing 1 Growth rates, grain yields, soil water use and water-use efficiency. Crop and Pasture Science, 62, 947-959. https://doi.org/10.1071/CP11234

Harwell, R. L., Strickland, L., \& Jobes, R. (1976). Utilization of winter wheat pasture in Oklahoma. Oklahoma Agricultural Experiment Station: Oklahoma City, OK, USA.743.

Holman, J. D., Thompson, C. R., Hale, R. L., \& Schlegel, A. J. (2009). Grazing effects on yield and quality of hard red and hard white winter wheat. Agronomy Journal, 101(4), 775-788. https://doi.org/10.2134/ agronj2008.0163x

Kelman, W. M., \& Dove, H. (2007). Effects of a spring-sown brassica crop on lamb performance and on subsequent establishment and grain yield of dual purpose winter wheat and oat crops. Australian Journal of Experimental Agriculture, 47, 815-824. https://doi.org/101071/ EA06152

Kelman, W. M., \& Dove, H. (2009). Growth and phenology of winter wheat and oats in a dual- purpose management system. Crop \& Pasture Science, 60(10), 921-932. https://doi.org/10.1071/CP09029

Kirkegaard, K., Sprague, S., Lilley, J., Bell, L. (2016). Managing dual purpose crops to optimise profit from grazing and grain yield North. [2018-01-12]. https://grdccomau/resources-andpublications/grdcupdate-papers/tab-content/grdc-updatepapers/2016/02/managingdual-purpose-crops-to-optimiseprofit-from-grazing-and-grain-yield

Mishra, A. K., Mottaleb, K. A., Khanal, A. R., \& Mohanty, S. (2014). Abiotic stress and its impact on production efficiency: The case of rice farming in Bangladesh. Agriculture, Ecosystems \& Environment, 199, 146-153. https://doi.org/10.1016/j.agee.2014.09.006

Royo, C., Montesinos, E., Molina-Cano, J. L., \& Serra, J. (2006). Triticale and other small grain cereals for forage and grain in Mediterranean conditions. Grass and Forage Science, 48(1), 11-17. https://doi. org/10.1111/j.1365-2494.1993.tb01831.x

Wagle, P., Gowda, P. H., Northup, B. K., Turner, K. E., Neel, J. P., Manjunatha, P., \& Zhou, Y. (2018). Variability in carbon dioxide fluxes among six winter wheat paddocks managed under different tillage and grazing practices. Atmospheric Environment, 185, 100-108. https://doi. org/10.1016/j.atmosenv.2018.05.003

Winter, S. R., \& Thompson, E. K. (1990). Grazing winter wheat I Response of semidwarf cultivars to grain and grazed production systems. Agronomy Journal, 82, 33-37. https://doi.org/10.2134/agronj1990. $00021962008200010007 x$

Winter, S. R., Musick, J. T. (1991). Grazed wheat grain yield relationships. Agronomy Journal, 83(1), 130-135. https://doi.org/10.2134/agronj19 $91.00021962008300010030 x$

Winter, S. R., Thompson, E. K., \& Musick, J. T. (1990). Grazing winter wheat: II. Height effects on response to production systems. Agronomy Journal, 82, 37-41. https://doi.org/10.2134/agronj1990.000219620 $08200010008 x$

Zadoks, J. C., Chang, T. T., \& Konzak, C. F. (1974). A decimal code for growth stages of cereals. Weed Research, 14, 415-421.

Zeleke, K. T. (2019). Effect of grazing time and intensity on growth and yield of spring wheat (Triticum aestivum L). Journal of Integrative Agriculture, 18(5), 1138-1147, https://doi.org/10.1016/S2095$3119(18) 62125-2$ 